\title{
KONTRIBUSI SISTEM PENGHARGAAN DAN LINGKUNGAN KERJA TERHADAP EFEKTIFITAS KERJA PEGAWAI PADA KANTOR DINAS PENDIDIKAN KOTA PADANG
}

\author{
Yulian Putri, Riri Mayliza \\ Sekolah Tinggi Ilmu Ekonomi "KBP" \\ ririmayliza@akbpstie.ac.id
}

\begin{abstract}
This study aims to determine the contribution of the award system and the work environment either partially or simultaneously to the effectiveness of employees working in the office of Padang City Department of Education. This research is a quantitative and a population study. The subjects were all employees at the Padang Kota Education Office with the number of 120 employees, but our data if only the data after re-deployed only 54 respondents. data collection using kuiosoner that have been tested for validity and reliability and test the hypothesis by using test $f$ and test $t$ test. he results showed that: 1) there is a contribution to the effectiveness of the award system of employees working in the office of Padang City Department of Education indicated from the results ( $t$ tabel, sig 0.05, $d f(54-2-1)=$ 51). It can be seen that the value of $t 2,546>t$ tabel 1.675, and nilai sig $0.014<0.05$, it can be concluded that Ha Ho accepted and rejected it means that the reward system has a significant influence on the effectiveness of work. Hasi researchers expected to benefit the next writer.
\end{abstract}

Keywords: Choice System, Work Environment and Work Effectiveness

\section{PENDAHULUAN}

Berbicara tentang efektifitas kerja pegawai suatu kelembagaan dapat dikatakan tidak terlepas dari keterkaitannya dengan system penghargaan dan kondisi lingkungan kerja yang diberikan lembaga /instansi kepada para pegawai yang terlihat dalam kelembagaan tersebut .

Efektifitas kerja dan kinerja aparatur pemerintahan menjadi sorotan bagi semua kalangan masyarakat. Paradigma yang muncul ditengahtengah masyarakat bahwa kerja kurang baik, banyak oknum aparatur pemerintahan yang korupsi, kolusi, tidak displin dan sebagainya. Anggapan masyarakat tidak dapat kita terima dan kita tolak seutuhnya, kenyataan ini sudah merupakan sebuah budaya di dalam pemerintahan 
mulai dari pusat sampai ke daerah. Untuk merubah pandangan masyarakat, maka pemerintah melakukan berbagai upaya guna perbaikan dimasa mendatang antara lain dengan meningkatkan SDM, penegakan hukum dan pemberian tanda penghargaan bagi yang berprestasi, meningkatkan kesejahteraan dan sebagainya.

\section{Perumusan Masalah}

Untuk mencapai tujuan proposal penelitian ini, maka mengangkat masalah dengan menjawab pertanyaan:

1. Apakah terdapat kontribusi sistem penghargaan terhadap efektifitas kerja Pegawai Dinas Pendidikan Kota Padang?

2. Apakah terdapat kontribusi antara lingkungan kerja terhadap efektifitas Pegawai Dinas Pendidikan Kota Padang?

\section{LANDASAN TEORI}

\section{Sistem Penghargaan}

Penghargaan dianggap predikat tinggi yang di dapatkan seseorang, orang mendapatkan penghargaan tentulah orang yang telah berbuat yang terbaik bagi orang lain atau lembaga. Penghargaan diberikan kepada seseorang aparatur (pegawai) merupakan sebuah bentuk balas jasa atas prestasi kerja yang dilakukannya. Dalam lingkungan kerja organisasi penghargaan diberikan dalam dua bentuk yaitu kenaikan pangkat atau jabatan dan pemberian insentif tambahan (kompensasi).

Menaikkan pangkat secara otomatis akan menambah kompensasi/insentif atau gaji seseorang. ( Mustopa , 2011 ) Seseorang mau bekerja dari pagi sampai sore karena tahu bahwa ia akan mendapat kan insentif berupa gaji, jika sesorang tahu akan mendapapatkan penghargaan, maka ia pun akan bekerja lebih giat dalam bekerja. Makna lain dari kata penghargaan adalah pemberian uang secara langsung upah , gaji, insentif, bonus dan dapat pula beberbentuk pembayaran tidak langsung asuransi, liburan atas biaya perusahaan dan dapat ula berupa ganjaran bukan uang jam kerja luwes, kntor bergengsi , pekerjaan yang lebih menantang ( Dessler 2005)

\section{Lingkungan Kerja}

Defenisi Lingkungan kerja

Secara umum lingkungan kerja dapat kita defenisikan merupakan serangkaian situasi dan aktifitas yang dilakukan oleh seluruh komponen organisasi atau lembaga. Barry Render \& jy heizer (2001 : 183) mendefenisikan lingkungan kerja yaitu:

Lingkugan fisik tempat kaeyawan bekerja yang mempengaruhi kinerja, keaman dan mutu kehidupan kerja mereka. Lingkungankerja yang kondusif memebrikan rasa aman dan memungkinkan para pegawai untuk dapat bekerja optimal

Kondisi lingkungan kerja yang tidak sehat membuat karyawan menjadi cemas akan kesehatan dan keselamatan kerja mereka. Lingkungan kerja yang tidak sehat juga berdampak pada terhadap ketenangan karyawan dalam melaksankan tugas, sebagi contoh lingkungan kerja yang 
bising berdampak jalannya komunikasi yang baik. Lingkungan kerja yang pengap membuat karyawan gelisah dan lingkungan kerja yang tidak masuk cahaya cukup menjadikan karyawan tidak dapat bekerja serta arus litrik yang tidak cukup menjadikan karyawan tidak dapat menggunakan teknologi yang menggunakan arus listrik. Lingkungan kerja yang sehat akan mendorong efektifitas kerja para karyawan dalam melaksanakan tugas. Robert C. Mill dalam A. Dale Timpe (1988: 3) mengatakan " Lingkungan kerja yang menyenangkan menjadi kunci pendorong bagi karyawan anda untuk menghasilkan kinerja puncak". Prestasi kerja yang kurang baik disebabkan oleh beberapa faktor antara lain lingkungan kerja, keterampilan sarana dan prasarana. Barry Render \& Jay Heider mengatakan " prestasi kerja karyawan di bawah standar mungkin di sebabkan sejumlah faktor mulai dari keterampilan kerja yang buruk hingga motivasi yang tidak cukup atau lingkungan kerja yang buruk.

\section{Efektifitas Kerja}

Pengertian efektifitas merupakan suatu konsep yang sangat luas, mencakup berbagai faktor di dalam maupun di luar organisasi. Hal ini menyebabkan terdapat berbagai pendangan para ahli tentang konsep tersebut. Siagian (2001:24) memberikan defenisi sebagai berikut : ' 'Efektivitas adalah pemanfaatan sumber daya, sarana dan prasarana dalam jumlah tertentu yang secara sadar ditetapkan sebelumnya untuk menghasilkan sejumlah barang atas jasa kegiatan yang dijalankannya. Efektivitas menunjukkan keberhasilan dari segi tercapai tidaknya sasaran yang telah ditetapkan. Jika hasil kegiatan semakin mendekati sasaran, berarti makin tinggi efektivitasnya

Menurut Indrawijaya (2001) : "Efektivitas adalah pemanfaatan sumber sarana dan prasarana dalam jumlah tertentu yang secara sadar ditetapkan sebelumnya untuk menghasilkan sejumlah pekerjaan tepat pada waktunya

Dapat disimpulkan efektifitas adalah kombinasi energi manusia dan kekuatan sarana dan prasaran dalam pencapaian tujuan organisasi atau lembaga secara efektif. Berarti "tujuan organisasi" hendaknya menjadi perhatian utama anggota organisasi terutama dalam hal pengambilan keputusan strategis dalam rangka memaksimumkan tujuan (Maximizing Goal) dan mengoptimumkan tujuan (Optimizing Goal).

\section{METODE PENELITIAN}

\section{Objek Penelitian}

Penelitian ini dilaksanakan pada aparatur pemerintahan/Pegawai Negeri Dinas Pendidikan Kota Padang.

\section{Jenis dan Sumber Data}

Adapun jenis data yang di gunakan adalah data kuantitatif. Sedangkan sumber data yang diperoleh dalam dalam penelitian adalah :

1. Data Primer, yaitu data yang diperoleh dari hasil wawancara dan hasil kuesioner yang ada pada Pegawai Dinas Pendidikan Kota Padang 
2. Data Sekunder, yaitu data yang dikumpulkan oleh penulis dari dokumen -dokumen yang ada pada Dinas Pendidikan Kota Padang

\section{Instrumen Penelitian}

Intrumen penelitian yang digunakan pada peneltian ini yaitu dengan menyusun daftar pertanyaan berdasarkan pada variabel bebas dan variabel tergantung .

Populasi dan Sampel

\section{Populasi}

Populasi dalam penelitian ini adalah Pegawai Dinas Pendidikan Kota Padang

\section{Sampel}

Sampel adalah sebagian yang diambil dari keseluruhan objek yang diteliti dan dianggap mewakili seluruh populasi

\section{Teknik Analisis Data}

Data yang diperoleh diolah dan disajikan dalam bentuk tabel, kemudian dianalisa secara kualitatif dan kuantitatif. Analisa kualitatif adalah adalah berkenaan dengan pengungkapan data tidak dalam bentuk angka-angka , tetapi berkenaan dengan nilai yang yang didasarkan pada hasil pengolahan data. Sebaliknya dalam analisa kuantitatif, data diinterpretasikan dalam bentuk angka-angka.

Analisa ini digunakan sebagai alat bantu statistik sehingga mempermudahkan penulis dalam menafsirkan data mentah yang diolah.

Untuk keperluan analisis data secara kuantitatif tersebut, dalam rangka mengukur variabel-variabel yang ada, variabel -variabel penelitian ini diukur dengan skla likert, yang dijabarkan menjadi indikator variabel yang kemudian dijadikan sebagai titik tolak penyusunan item-item instrumen, dapat berbentuk pernyataan atau pertanyaan melalui pengisiian kuesioner .

\section{Uji Validitas}

Menurut Arikunto ( 2002:144) validitasi adalah suatu ukuran yang menunjukan tingkat-tingkat kevalidan atau kesahian sesuatu instrument. Suatu instrument yang valid atau sahih mempunyai validitasi rendah. Sebuah instrument dikatakan valid apabila mampu mengukur apa yang diinginkan

\section{Uji Reabilitas}

Uji reabilitas bertujuan untuk mengukur instrument sehingga dipercaya dan menghasilkan data yang dapat dipercaya dan menghasilkan data yang dapat dipercaya juga . Menurut Arikunto (2005:54) "reliabitas menunjukkan pada satu pengertian bahwa sesuatu instrument cukup data dipercaya untuk digunakan sebagai alat pengumpulan data karena instrument tersebut sudah baik. Instrument yang baik tidak akan bersifat tendensius mengarahkan responden untuk memilih jawaban-jawaban tertentu. 


\section{Uji Hipotesis}

Uji t

Untuk menguji kebenaran hipotesis dilakukan adalah pengujian secara parsial melalui uji t yang dilihat berdasarkan table coefficient nilai p-value untuk setiap variable. Uji t pada dasarnya menunjukan seberapa jauh pengaruh satu variable indenpenden secara individual dalam menerangkan variable dependen ( Ghozali, 2005 ).

Uji f

Uji f pada dasarnya untuk menunjukan apakah semua variable independen atau bebas yang di masukan dalam model mempunyai pengaruh secara bersama-sama terhadap variable dependen atau terikat (Ghozali,2005).

\section{HASIL DAN PEMBAHASAN}

Dinas Pendidikan merupakan hal yang yang terpenting dalam pendidikan, ini berarti setiap manusia berhak dan berharap untuk selalu berkembang dalam pendidikan. Sebagaimana dijelaskan dalam UUD 1945 Pasal 28C ayat (1) yang berbunyi "Setiap orang berhak mengmbangkan driri melalui pemenuhan kebutuhan dasarnya, berhak mendapatkan pendidikan dan memperoleh manfaat dari ilmu pengetahuan dan teknologi ,seni dan budaya demi peningkatan kualitas hidupnya dan demi kesejahteraan umat manusia”. Dan Dinas Pendidikan juga merupakan unsur pelaksanaan pemerintahan daerah, dipimpin oleh seorang Kepala Dinas yang berada dibawah dan bertanggung jawab kepada Bupati melalui sekretriat daerah. Terkait dengan sejarah Dinas Pendidikan pemerintah kembali mengeluarkan Peraturan No.11 Tahun 1989 yang berisi penyerahan sebagian urusan pemerintahan di bidang pendidikan dan kebudayaan kepada pemerintah daerah, kemudian disusul pada 1990 dengan keluarnya Perda No.3 Tahun 1990 membahas tentang dibentuknya Dinas Pendidikan dan Kebudayaan , kemudian disusul dengan kebijakan pada tahun 2001 tentang otonomi Derah sehingga masalah pendidikan disebuah daerah menjadi tanggung jawab daerah masing-masing meski memang harus tetap melakukan koordinasi dengan Dinas Pendidikan di Pusat.

\section{Pembahasan}

Untuk variabel $\mathrm{X} 1$ sistem dapat dilihat bahwa nilai $\mathrm{r}$ hitung untuk Item 1 adalah $0,740>0,268$, artinya Item 1 dapat dinyatakan valid, karena $\mathrm{r}$ hitung $>\mathrm{r}$ tabel. Begitu juga untuk Item pertanyaan $2-7$.

Untuk variabel X2 lingkungan kerja ada 7 item pertanyaan yang diuji validitasnya. Dari tabel diatas dapat dilihat bahwa nilai $r$ hitung untuk Item 1 adalah 0,658 >0,268, artinya Item 1 dapat dinyatakan valid, karena $r$ hitung $>r$ tabel. Begitu juga untuk Item pertanyaan $2-7$. Untuk variabel Y efektifitasa kerja ada 7 item pertanyaan yang diuji validitasnya. Dari tabel diatas dapat dilihat bahwa nilai $r$ hitung untuk Item 1 adalah 0,592 > 0,268, artinya Item 1 dapat dinyatakan valid, karena $\mathrm{r}$ hitung $>\mathrm{r}$ tabel. 
Begitu juga untuk Item pertanyaan 2, 3,6 dan 7, terlihat bahwa nilai $r$ hitung untuk semua Item lebih besar dari nilai $r$ table

\section{KESIMPULAN DAN SARAN \\ Kesimpulan}

Terdapat Kontribusi system penghargaan terhadap efektifitas kerja pegawai pada kantor Dinas Pendidikan Kota Padang. Hal ini ditunjukan oleh nilai $r$ hitung $>r$ table $0(0,740>0,268)$ dengan nilai dengan nilai sig. 0,000

Tidak terdapat pengaruh Kontribusi lingkungan kerja terhadap efektifitas kerja. Hal tersebut ditunjukan darihasil uji T hitung1,960 > t tabel 1.675, dannilai sig $0.055>0.05$.maka dapat disimpulkan bahwa Ho diterima dan Ha ditolak

Terdapat masing-masing variable independen system penghargaan, lingkungan kerja secara bersama-sama berpengaruh signifikan terhadap efektifitas kerja. Terlihat bahwa nilai $\mathrm{F}$ hitung sebesar 10,052 dengan angka signifikan 0.000. jika dibandingkan $f$ table sehingga diperoleh nilai $\mathrm{F}$ table untuk model regresi ini adalah 3,17. Maka dapat disimpulkan bahwa dengan menghasilkan nilai $\mathrm{F}$ Hal tersebut ditunjukan dengan hasil uji Fhitung 10,052 > F tabel 3,17 dan angka signifikan $0.000<0.05$.

\section{Saran}

Dinas Pendidikan Kota Padang sebaiknya bisa menghargai pegawainya dengan memberikan semacam penghargaan tersebut dapat bersifat material ( bonus, hadiah), maupun yang bersifat non material ( pujian-pujian, pengakuan ). Ini berguna untuk lebih meningkatkan efektifitas kerja pegawai

Dinas Pendidikan Kota Padang perlu mempertimbangkan kembali masalah balas jasa kepada karyawan selain gaji atau upah, juga diberikan tambahan penghasilan

Pegawai Dinas Pendidikan Kota Padang perlu mempertimbangkan kembali masalah lingkungan kerja pegawai yang hanya mengutamakan penghargaan dalam efektifitas kerja pegawai tersebut.

\section{DAFTAR PUSTAKA}

Aldi, Y., \& Susanti, F. (2019). Pengaruh Stress Kerja Dan Motivasi Kerja Terhadap Prestasi Kerja Karyawan Pada PT. Frisian Flag Indonesia Wilayah Padang. https://doi.org/10.31227/osf.io/et4rn

Fendi, Z., \& Susanti, F. (2018). Pengaruh Kepuasan Kerja Terhadap Turnover Intention Dengan Komitmen Organisasi Sebagai Variabel Intervening Pada CV. Belibis Pariaman. https://doi.org/10.31227/osf.io/wumgx

Junaidi, R., \& Susanti, F. (2019). Pengaruh Gaya Kepemimpinan Dan Budaya Organisasi Terhadap Kinerja Pegawai Pada UPTD 
Baltekkomdik Dinas Pendidikan Provinsi Sumatera Barat. https://doi.org/10.31227/osf.io/bzq75

Lubis, A. Y. O., \& Susanti, F. (2019). Pengaruh Gaya Kepemimpinan Dan Kompensasi Terhadap Prestasi Kerja Karyawan (Studi pada PT Japfa Comfeed Indonesia (JCI) Tbk Devisi Fam 1. https://doi.org/10.31227/osf.io/7tbrg

Ridho, M., \& Susanti, F. (2019). Pengaruh Stres Kerja Dan Motivasi Kerja Terhadap Kepuasan Kerja Pada Karyawan Bank Mandiri Syariah Cabang Padang. https://doi.org/10.31227/osf.io/pa2cg

Susanto, R. (2018). Pengawasan Dan Lingkungan Kerja Terhadap Kinerja Karyawan PT. Bussan Auto Finance. https://doi.org/10.31227/osf.io/m3kge

Widodo, B. H., \& Susanti, F. (2019). Pengaruh Human Relation (Hubungan Antar Manusia), Lingkungan kerja Terhadap Etos Kerja karyawan (Studi Kasus Pada PT. Pelindo Teluk Bayur Padang ). https://doi.org/10.31227/osf.io/dxm8a

Yudistira, D. S., \& Susanti, F. (2019). Pengaruh Motivasi Kerja Dan Budaya Kerja Terhadap Kinerja Karyawan Dinas Pemberdayaan Masyarakat Dan Desa, Pengendalian Penduduk Dan Keluarga Berencana Kabupaten Pesisir Selatan. https://doi.org/10.31227/osf.io/jk54m 